\title{
Divided Nation: The North-South Cleavage in Italian Tax Compliance
}

\author{
John D’Attoma, European University Institute
}

It is well known that tax compliance is low in Italy, and lower in the South than in the North. Many scholars have examined Italian taxpayer behavior, mainly using experiments and surveys. However, little attention has been given to the historical circumstances that have shaped divergent taxpayer behavior by Northern and Southern Italians. This article uses historical data from Italian unification through the Second Republic to assess the effects of Italy's major formal institutions (the church, state, and political parties) and informal institutions (clientelism) on Italian tax behavior. It argues that nineteenth-century unification had significant repercussions on the two most important institutions in Italy-the Catholic Church and the state-and hence led to two different kinds of clientelism. Since Southern clientelism favored private interests and Northern clientelism led to the construction of public institutions, this created two different tax compliance environments.

Keywords: comparative political economy, tax compliance, Italy, tax morale, historical institutionalism

$\mathrm{F}$

ormer Italian Prime Minister Silvio Berlusconi once famously claimed that the "evasion of high taxes was a God-given right."' Tax evasion costs the Italian state an estimated 120 billion euros each year in lost revenue, ${ }^{2}$ but it varies greatly between the North and South of Italy. In the Northern regions from Lombardy to Lazio, evasion of the regional tax on production (Imposta Regionale sulle Attivita Produttive, or IRAP) ranges from about $13 \%$ to $54 \%$; in the South (the Mezzogiorno), covering Molise to Sicily, it ranges from about 54\% to $94 \%$ (see

I would like to thank Professors Sven Steinmo, Fred Pampel, Clara Volintiru, David Bruner, Kenneth Thomas, Fred Cocozzelli, David Kimball, Dave Robertson, and Stephen Brooker for their helpful comments. I also thank the four anonymous referees and the editors at Polity for the valuable feedback. This article draws on the "Willing to Pay" project funded by the European Research Council Agreement no. 295675.

1. Jabeen Bhatti et al., "Tax Evaders in Greece, Spain, and Italy Better Beware," USA Today, January 31, 2012, at http://usatoday30.usatoday.com/news/world/story/2012-01-29/tax-evaders -greece-spain-italy/52822942/1.

2. Alessandro Santoro, L'Evasione Fiscale (Bologna, Italy: Mulino, 2010).

Published online December 28, 2016. http://dx.doi.org/10.1086/689982

Polity, volume 49, number 1 (January 2017), pp. 69-99. 0032-3497/2017/4901-0004\$10.00.

(C) 2017 Northeastern Political Science Association. All rights reserved. 


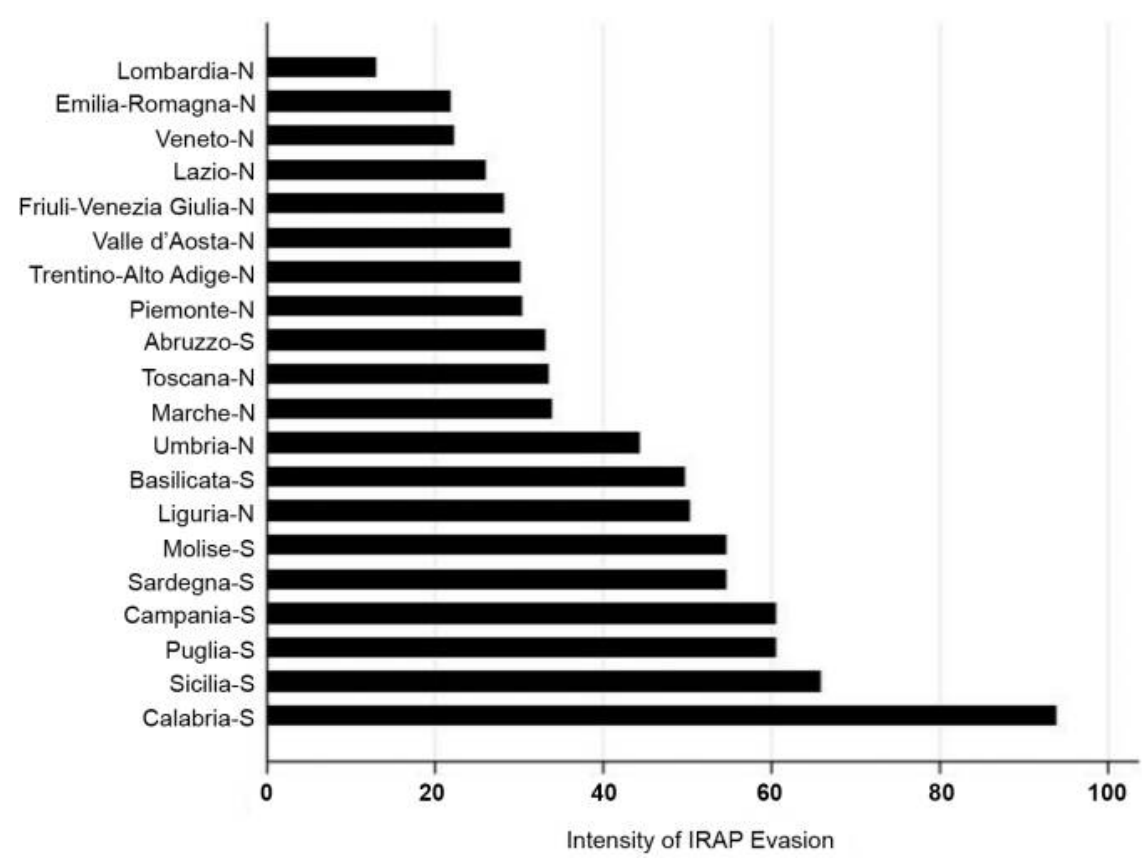

Figure 1. Intensity of Evasion of the Regional Production Tax (IRAP) by Region, 1998-2002 Source: ISTAT (see note 3 in text above); Santoro, L'Evasione Fiscale (see note 2 in text above).

Figure 1). Underground labor as a percentage of regular work, a common indicator for tax evasion, averaged an estimated $9.8 \%$ in in the Northern and Central regions of Italy in 2004 but reached $18.8 \%$ in the South. ${ }^{3}$,

One explanation for these disparities, promoted by Robert Putnam and others, depicts Southern Italians as less endowed with civic virtue and social capital, which is reflected in their lower levels of economic development and government

3. Bruno Chiarini and Elisabetta Marzano, "Structural and Cyclical Patterns of Underground Labour Input in Italy From 1980 to 2004," SSRN Electronic Journal (2007): 1-9. The method used by the Italian National Institute for Statistics (ISTAT) to estimate underground labor is well documented in the OECD Handbook, "Measuring the Non-Observed Economy," 2002, at https://www.oecd.org/std/na/1963116.pdf. It has been argued that Central Italy, made up of Umbria, Toscany, Lazio, Marche, and Emilia Romagna, should be considered a distinct region known as the Center. However, more often the North-South cleavage is defined at Rome's southern border. In the rest of the article, I thus consider the central regions, which are some of the most developed regions in Italy, to be part of the North. 
performance. ${ }^{4}$ Here civic virtue is defined as high civic awareness and a shared consensus regarding the legitimacy of political institutions and public policy, together with political competence and trust. ${ }^{5}$ Social capital refers to features of social life, such as networks and trust, that facilitate civic participation. ${ }^{6}$

This line of research typically links development to the cultural underpinnings of society. A centuries-old stereotype would have us believe that the Italian "character is faulty, and that this faultiness even explains much of the social and political problems of their country today." Indeed, Europeans perceive Italians as the least trustworthy of Western European nations. ${ }^{8}$ First Edward Banfield, followed by Robert Putnam and his colleagues, suggested that Southern Italy, in particular, is a region characterized by "amoral familism." Such societies, tied by "bonding" social capital, "emphasize family relations to the exclusion of all

4. Robert Putnam, Robert Leonardi, and Raffaella Nanetti, Making Democracy Work: Civic Traditions in Modern Italy (Princeton, N.J.: Princeton University Press, 1994); Edward Banfield, The Moral Basis of a Backward Society (Glencoe, Ill.: Free Press, 1967); Fabio Sabatini, "Social Capital, Public Spending, and the Quality of Economic Development," SSRN Electronic Journal (2006): 1-45; Fabio Sabatini, "The Role of Social Capital in Economic Development: Investigating the Causal Nexus Through Structural Equations Models," SSRN Electronic Journal (2005): 1-27; Maria Bigoni et al., "Amoral Familism, Social Capital, or Trust? the Behavioural Foundations of the Italian North-South Divide," The Economic Journal (2015): 1-24; Roberto Cartocci, "L'Unificazione Fallita: il Sud e il Capitale Sociale," Vita e Pensiero 6 (2006): 105-13.

Bordandini and Cartocci have confirmed the divergence in social capital between Northern and Southern Italy using a variety of indicators, including electoral participation, newspaper readership, volunteering, and blood donations. See Paola Bordandini and Roberto Cartocci, "Quante Italie: Il Ritorno al Tradizionale Cleavage Tra Nord e Sud del Paese," Cambio 8 (2014): 47-65. Additionally, Joan Barceló presents evidence that supports Putnam et al.'s theory, suggesting a long history of civic community in the historical republics of Italy, while ruling out possible intervening variables that might have significantly influenced certain connections, such as the link between the Communist Party of Italy and civicness. See Joan Barceló, "Re-Examining a Modern Classic: Does Putnam's Making Democracy Work Suffer From Spuriousness?, Modern Italy 19 (2014): 457-71.

5. Gabriel A. Almond and Sidney Verba, The Civic Culture (Princeton, N.J.: Princeton University Press, 1963), 30-32.

6. Putnam et al., Making Democracy Work (see note 4 above).

7. Silvana Patriarca, Italian Vices: Nation and Character From the Risorgimento to the Republic (Cambridge, U.K.: Cambridge University Press, 2010), at 5.

8. Gerry Mackie, "Patterns of Social Trust in Western Europe and Their Genesis," in Trust in Society, ed. Karen Cook (New York: Russell Sage Foundation, 2001), 245-82. Italian's perception of one another varies across regions. See Putnam et al., Making Democracy Work (see note 4 above); Guido Tabellini, "Culture and Institutions: Economic Development in the Regions of Europe," Journal of the European Economic Association 8 (2010): 677-716. 
others." On the other hand, "bridging" social capital draws individuals together regardless of socioeconomic status, race, or ethnic background. ${ }^{10}$ Ethical behavior in a "bonding" society is confined to the immediate family and closest friends. Taxes therefore can be perceived as hurting the family by imposing a cost in order to benefit people outside the familial unit.

Nevertheless, Putnam's and Banfield's works have been met by a litany of critics who suggest that Putnam's selection of data is problematic. Furthermore, they argue that civic life was not completely absent in the South, and that progressive politics in the North and the process of state building drove asymmetric economic performance and governance. ${ }^{11}$ Salvatore Lupo, renowned for his work on the Southern question, claims that Putnam et al. purposely select data points and variables that confirm their theory while disregarding those that might contradict their premise. ${ }^{12}$ Sidney Tarrow contends that Putnam et al. oversimplify regional definitions by joining Northern regions with both long and short republican histories into one variable. ${ }^{13}$ Furthermore, Paolo Farneti unveiled evidence that revealed Puglia and Sicily as having had the second and third highest percent of union membership in Italy in $1914 .^{14}$ This would suggest that civic life was actually thriving in the beginning of the twentieth century in Southern Italy. Tarrow also points out that Southern Italy in the 1980s and 1990s experienced major growth in civic associations and the formation of civic culture, while the North was rife with corruption scandals. Carlo Triglia, for example, found a total of 6,400 associations in the South, formed mostly after $1980 .{ }^{15}$

Moreover, the social capital literature often confounds explanations with outcomes, which implies that public institutions and the elites that govern those in-

9. Francis Fukuyama, "Social Capital and the Global Economy," Foreign Affairs 74, no. 5 (1995): $89-103$ at 91.

10. Robert D. Putnam, Bowling Alone: The Collapse and Revival of American Community (New York: Simon and Schuster: 2001), 22-24.

11. Margaret Levi, "Social and Unsocial Capital: A Review Essay of Robert Putnam's Making Democracy Work," Politics \& Society 24 (1996): 45-55; Sidney Tarrow, "Making Social Science Work Across Space and Time: A Critical Reflection on Robert Putnam's Making Democracy Work," American Political Science Review 90 (June 1996): 389-97; Filippo Sabetti, Search for Good Government: Understanding the Paradox of Italian Democracy (Montreal: McGillQueen's University Press, 2000).

12. Salvatore Lupo, "Usi e Abusi del Passato: Le Radici dell'Italia di Putnam," Meridiana no. 18 (1993): 151-68.

13. Tarrow, "Making Social Science Work Across Space and Time" (see note 11 above).

14. Paolo Farneti, Sistema Politico e Società Civile: Saggi di Teoria e Ricerca Politica, vol. 25 of Pubblicazioni dell'Istituto di scienze politiche dell'Università di Torino (Turin, Italy: Giappichelli, 1971), 291.

15. Carlo Trigilia, Cultura e Sviluppo. L'associazionismo nel Mezzogiorno (Rome: Donzelli, 1995). 
stitutions are somehow responsible for fostering a civic citizenry. For example, Levi suggests that a government's ability to protect property rights and a meritbased society (one opposed to the clientelism or nepotism found in southern Italy) instill a generalized trust in society. ${ }^{16}$ Even Putnam mentions that the regimes prior to unification intensified distrust and vertical ties in the South, but he barely mentions how unification reduced the South to "semi-colonial status," and "its fragile commercial sector brutally merged with the North's more flourishing economy, a uniform tax system and customs union imposed on its vulnerable industries, and brigandage rooted out by a full-scale military campaign." ${ }^{\prime 17}$ Finally, Filippo Sabetti contends that the growth of institutions and ecclesial infrastructure since the eighteenth century better explain the Italian political economy than the "amoral familism" stressed by Putnam. ${ }^{18}$

Like these critics, I contend that the moralist argument fails to account for the institutional environment (such as a period of progressive politics, political competition, or strife between the Church and the state) from which behavior may manifest. While the vast majority of these scholars analyze the gap in economic and social development, I am concerned with why taxpayer behavior differs so greatly. Simply put, tax behavior reflects the quality of and perceptions about the government institutions to which a taxpayer is contributing. There is ample evidence in the literature suggesting that individuals are more likely to pay taxes if they believe that the government is spending their tax money honestly and efficiently. ${ }^{19}$

16. Levi, "Social and Unsocial Capital (see note 11 above).

17. Tarrow, "Making Democracy Work Across Space and Time," 394 (see note 11 above).

18. Sabetti, Search for Good Government (see note 11 above).

19. Ronald G. Cummings et al., "Tax Morale Affects Tax Compliance: Evidence From Surveys and an Artefactual Field Experiment," Journal of Economic Behavior \& Organization 70 (2009): 447-57; Jonas Edlund, "Trust in Government and Welfare Regimes: Attitudes to Redistribution and Financial Cheating in the USA and Norway," European Journal of Political Research 35 (1999): 341-70; Bruno Frey and Lars Feld, "Deterrence and Morale in Taxation: An Empirical Analysis," (CESifo Working Paper Number 760, 2002); Bruno Frey and Benno Torgler, "Tax Morale and Conditional Cooperation," Journal of Comparative Economics 35 (2007): 136-59; Margaret Levi, Of Rule and Revenue (Berkeley: University of California Press, 1989); Margaret Levi, Audrey Sacks, and Tom Tyler, "Conceptualizing Legitimacy, Measuring Legitimating Beliefs," American Behavioral Scientist 53 (2009): 354-75; Werner Pommerehne, Albert Hart, and Bruno Frey, "Tax Morale, Tax Evasion and the Choice of Policy Instruments in Different Political Systems," Public Finance 49 (1994): 52-69; John Scholz and Mark Lubell, "Trust and Taxpaying: Testing the Heuristic Approach to Collective Action," American Journal of Political Science 42 (1998): 398-417; Kent W. Smith, Reciprocity and Fairness (Washington, D.C.: American Bar Foundation, 1990); Kent Smith and Loretta Stalans, "Encouraging Tax Compliance with Positive Incentives: A Conceptual Framework and Research Directions," 
Taxation mobilizes citizens to demand accountability from their government; conversely, a lack of government accountability can motivate individuals to evade their responsibilities. ${ }^{20}$ In many ways, taxation is the linchpin binding government accountability to citizen responsibility. Paying taxes is a form of indirect political participation, which, in theory, should make government more answerable to taxpayers. To better illustrate this link, data from Bordandini and Cartocci, Charron et al., and Bruno Chairini and Elisabetta Marzano are presented in Figures $2 \mathrm{a}-2 \mathrm{c}$; $^{21}$ they suggest a clear correlation between quality of government, voter participation, and generalized trust on the $x$-axis, and the percent of irregular work (underground labor), provided as a proxy for tax evasion, in each Italian region, on the $y$-axis. ${ }^{22}$ I use voter participation as a proxy for trust in government. In each case, the relationship is sorted along the North-South cleavage line, with the South demonstrating less trust, lower levels of voter participation, and lower quality of government, all of which are negatively correlated with percent of underground employment. Indeed, data from a number of scholars suggest a clear correlation in Italy between tax evasion (as measured by underground labor) and measures of government accountability. ${ }^{23}$ Southern regions have higher levels of underground labor and lower levels of trust, voter participation, and quality of government.

According to Michael L. Ross, "Both the size of the tax burden, and the quality and quantity of government spending matter; citizens ultimately care about the

Law \& Policy 13 (1991): 35-53; Benno Torgler and Friedrich G. Schneider, "Shadow Economy, Tax Morale, Governance and Institutional Quality," SSRN Electronic Journal (2007).

20. Samuel P Huntington, The Third Wave (Norman: University of Oklahoma Press, 2012); Laura Paler, "Keeping the Public Purse: An Experiment in Windfalls, Taxes, and the Incentives to Restrain Government," American Political Science Review 107 (2013): 706-25.

21. Bordandini and Cartocci, "Quante Italie?" (see note 4 above); Chiarini and Marzano, "Structural and Cyclical Patterns" (see note 3 above); Nicholas Charron, Lewis Dijkstra, and Victor Lapuente, "Mapping the Regional Divide in Europe: A Measure for Assessing Quality of Government in 206 European regions," Social Indicators Research 122 (2015): 315-46.

22. Santoro, L'Evasione Fiscale (see note 2 above). It is worth noting that both Liguria and Abruzzo do not conform to the expected North-South pattern. The Southern region of Abruzzo performs just slightly worse on the Quality of Government Index (see Table 2 below) than the Northern region of Liguria, but the percentage of self-employed in Liguria is approximately one percent higher, according to the National Institute for Statistics (ISTAT); see http://noi-italia .istat.it. The combination of lower than average quality of government and a high rate of selfemployed individuals in Liguria could explain this unexpected result. In addition, the Northern regions of Tuscany, Umbria, and Marche all have higher rates of self-employed individuals than Abruzzo.

23. Bordandini and Cartocci, "Quante Italie?" (see note 4 above); Chiarini and Marzano, "Structural and Cyclical Patterns" (see note 3 above); Nicholas Charron et al., "Mapping the Regional Divide in Europe” (see note 21 above). 


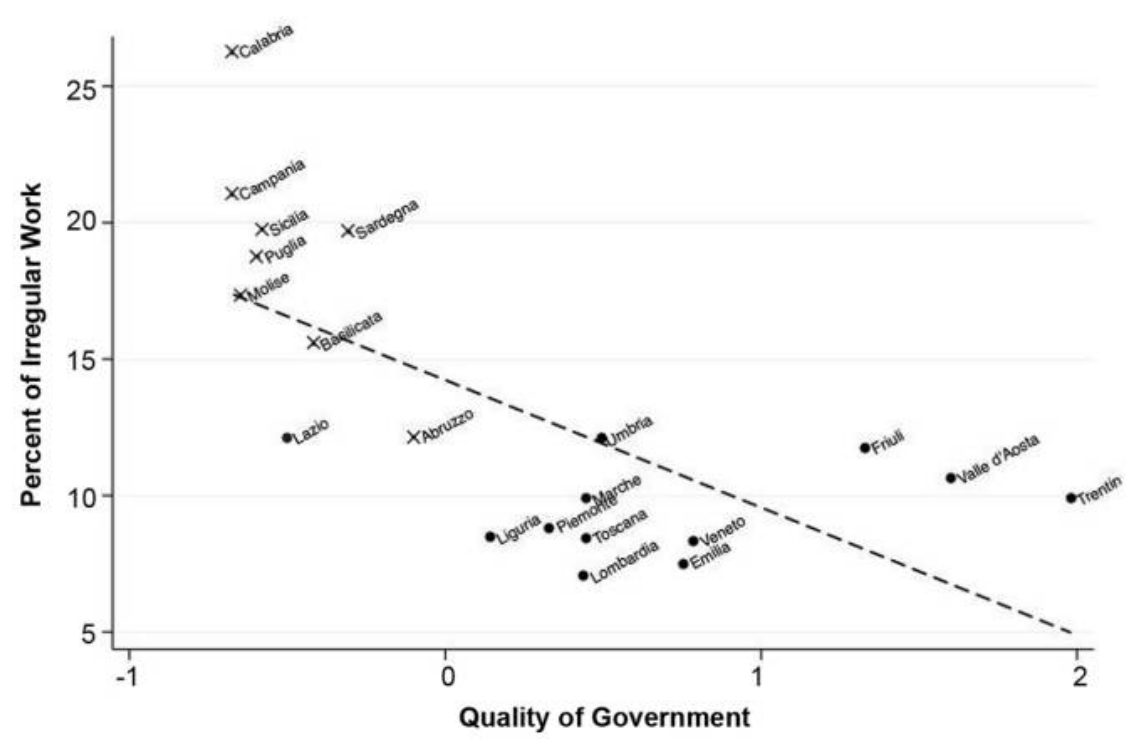

Figure 2a. Irregular Work over Quality of Government Key: $\mathrm{X}=$ South; $\bullet=$ North

Sources: Charron, et al., "Mapping the Regional Divide in Europe" (see note 21 in text above); Borandini and Cartocci, "Quante Italia?" (see note 4 in the text above); Chiarini and Marzano, "Structural and Cyclical Patterns" (see note 3 in text above).

'price' they pay for the government services they receive." ${ }^{24}$ It is no wonder that tax evasion is so rampant in Southern Italy. Italy as a whole consistently ranks near the bottom on the Quality of Government index ${ }^{25}$ compared to other European nations, while the South ranks considerably lower than the North (see Tables 1 and 2). Furthermore, Italy's $44 \%$ tax burden (ratio of tax revenue to GDP)

24. Michael L Ross, “Does Taxation Lead to Representation?” British Journal of Political Science 34 (April 1, 2004): 229-49, at 234.

25. This index is based on 450 variables with the unit of observation being region of the European Union. There were 251 regions included in the Quality of Government EU regional index. Italy is made up of 12 regions in the North and 8 in the South. The mean QoG index in the South is -1.58 and -.0 .25 in the North. A difference of means, two-tailed t-test is significant at the .001 level.

The Quality of Government standard index, developed at the Quality of Government Institute at Gothenburg University, is a based on a set of nationally representative public opinion surveys of over 85,000 participants conducted about perceptions of local education, health, and law enforcement institutions. Researchers asked participants to rate each of the three institutions on quality, impartiality, and corruption. For more information see Jan Teorell et al., “The Quality of Government Dataset," The Quality of Government Institute (Gothenborg, Sweden, University of Gothenborg, 2011). 


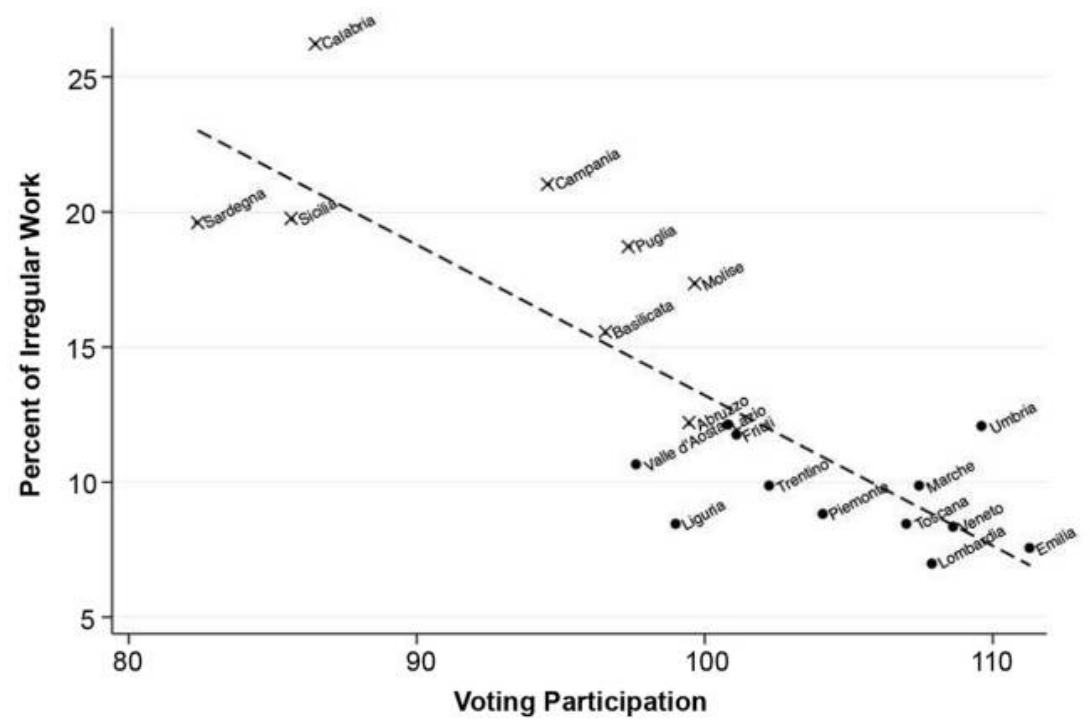

Figure 2b. Irregular Work over Voter Participation Key: $\mathrm{X}=$ South; $\bullet=$ North

Sources: See sources for Figure 2a.

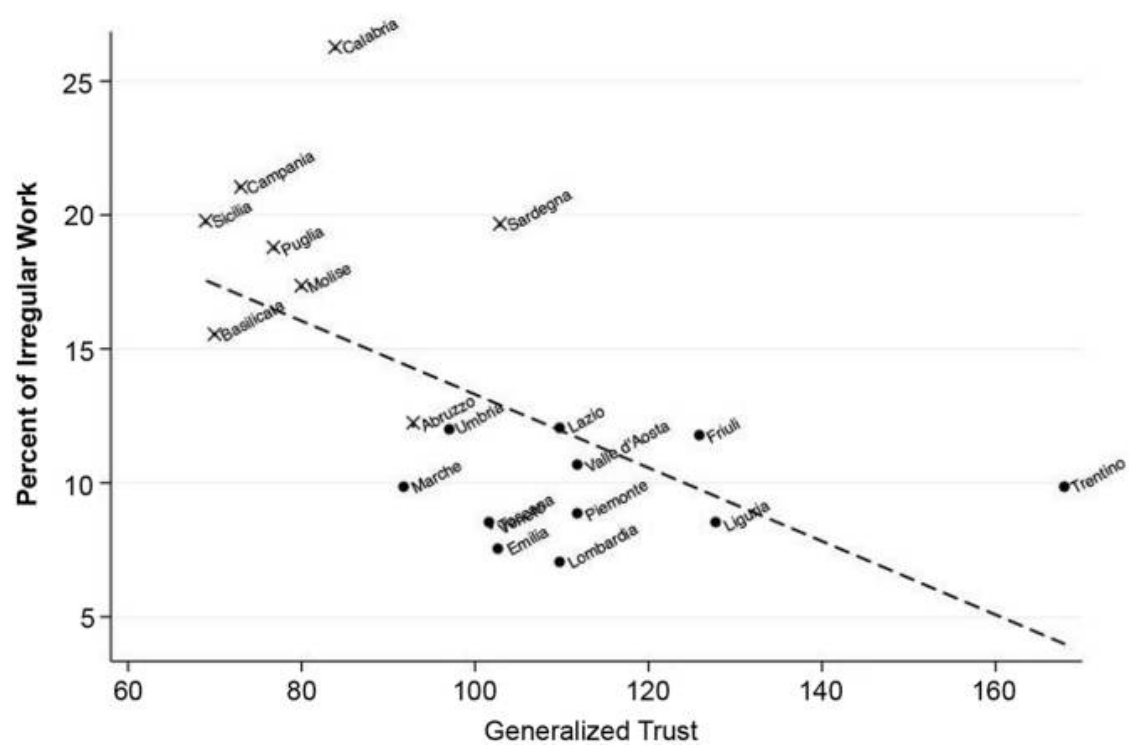

Figure 2c. Irregularity of Work over Generalized Trust Key: X $=$ South; $\cdot=$ North

Sources: See sources for Figure 2a. 
Table 1. Quality of Government Index in 14 Western European Countries

\begin{tabular}{lrrrr}
\hline Country & Quality & Impartiality & Corruption & Average \\
\hline Finland & 1.657 & 1.296 & 1.266 & 1.406 \\
Netherlands & 0.956 & 1.445 & 0.912 & 1.104 \\
Denmark & 0.723 & 1.004 & 1.560 & 1.096 \\
Ireland & 0.705 & 1.046 & 1.252 & 1.001 \\
United Kingdom & 0.507 & 0.797 & 0.871 & 0.725 \\
Sweden & -0.030 & 1.128 & 0.897 & 0.665 \\
Belgium & 1.440 & -0.229 & 0.054 & 0.422 \\
Germany & 0.265 & 0.322 & 0.651 & 0.413 \\
Austria & 0.320 & 0.133 & 0.359 & 0.270 \\
Italy & $\mathbf{0 . 1 8 7}$ & $\mathbf{0 . 1 8 7}$ & $-\mathbf{0 . 6 3 4}$ & $-\mathbf{0 . 0 8 7}$ \\
Spain & 0.083 & -0.229 & -0.115 & -0.087 \\
France & 0.210 & -0.758 & 0.074 & -0.158 \\
Portugal & -0.259 & -0.848 & -0.745 & -0.617 \\
Greece & -1.287 & -0.655 & -1.304 & -1.082 \\
\hline
\end{tabular}

Source: Jan Teorell et al., "The Quality of Government Dataset” (see note 25 in text above).

is one of the highest in the European Union; only Denmark, Belgium, France, and Sweden have a higher tax burden. ${ }^{26}$ Because confidence in public institutions (i.e., the state and political parties) is a direct reflection of the quality of those institutions, if my view is correct, then Southern Italians should have less trust in their public institutions. Consequently, Southern Italians should be more likely to evade taxes.

In the next section, I outline the historical institutionalist approach. I employ this approach to argue that unique institutional circumstances-such as loyalty to the newly developed nation state in the North and to the Church in the South, and political competition between political parties in the North and a vast political monopoly in the South-have shaped a more positive perception of government among Northern Italians compared to their Southern neighbors, generating greater tax compliance in the North. In the historical analysis that follows, I then trace the ways in which unification pitted the Church against the state and the North against the South, providing a different experience with the state in the two regions and hence different preferences regarding taxation. I argue that the Catholic Church and the state after unification shaped two distinct attitudes towards

26. European Commission and European Union Eurostat, Taxation Trends in the European Union (Luxemberg: European Commission, 2012). 
Table 2. Quality of Government Index for Italian Regions

\begin{tabular}{lccc}
\hline Region & $\begin{array}{c}\text { European Quality of } \\
\text { Government Index }\end{array}$ & Region Score & $\begin{array}{c}\text { 2013 Rank } \\
\text { (among 236 European regions) }\end{array}$ \\
\hline Trento & 1.043 & 1.981 & 41 \\
Valle d'Aosta & 0.653 & 1.603 & 82 \\
Friuli-Venezia & 0.373 & 1.331 & 109 \\
Veneto & -0.186 & 0.788 & 146 \\
Emilia-Romagna & 0.217 & 0.757 & 149 \\
Umbria & -0.495 & 0.488 & 168 \\
Toscana & -0.533 & 0.450 & 170 \\
Marche & -0.535 & 0.448 & 172 \\
Lombardia & -0.542 & 0.442 & 174 \\
Piemonte & -0.652 & 0.335 & 190 \\
Liguria & -0.848 & 0.144 & $\mathbf{2 0 0}$ \\
Abruzzo & $-\mathbf{1 . 0 9 7}$ & $-\mathbf{0 . 0 9 7}$ & $\mathbf{2 0 4}$ \\
Sardegna & $-\mathbf{1 . 3 0 7}$ & $-\mathbf{0 . 3 0 2}$ & $\mathbf{2 0 8}$ \\
Basilicata & $-\mathbf{1 . 4 2 3}$ & $-\mathbf{0 . 4 1 4}$ & 211 \\
Lazio & -1.512 & -0.500 & $\mathbf{2 1 3}$ \\
Sicilia & $-\mathbf{1 . 5 8 8}$ & $-\mathbf{0 . 5 7 5}$ & $\mathbf{2 1 6}$ \\
Puglia & $\mathbf{- 1 . 6 0 4}$ & $\mathbf{- 0 . 5 9 0}$ & $\mathbf{2 2 0}$ \\
Molise & $\mathbf{- 1 . 6 6 0 9}$ & $\mathbf{- 0 . 6 4 5}$ & $\mathbf{2 2 2}$ \\
Calabria & $\mathbf{- 1 . 6 8 7}$ & $\mathbf{- 0 . 6 7 1}$ & $\mathbf{2 3 2}$ \\
Campania & $\mathbf{- 2 . 2 4 2}$ & -1.210 & \\
\hline
\end{tabular}

Source: Jan Teorell et al., "The Quality of Government Dataset" (see note 25 in the text above). Southern regions are in bold.

the state in Northern and Southern Italy, and thus, two different compliance environments. In the North, the high tax compliance environment was reinforced by a type of clientelism that emerged from strong political competition between the Christian Democrats, the Italian Socialist Party, and the Italian Communist Party. These parties provided resources to unions for public works projects in order to gain support of the large industrial base, which increased trust in public institutions. In the South, however, the low tax compliance environment was hardened by a form of clientelism driven by the Christian Democrats' political monopoly, which favored individualized, private goods instead of public goods, decreasing trust in public institutions and hence decreasing tax compliance. In sum, because Northerners have perceived their institutions as efficient and effective, they have been more likely to contribute to the state through taxation. In contrast, Southerners have perceived the state as inefficient and ineffective, leading them to circumvent their fiscal obligations. 


\section{The Historical-Institutionalist Approach}

The past is never dead. It's not even past. ${ }^{27}$

Historical institutionalists strive to answer "big" questions, such as variation between tax systems or welfare regimes among countries. The approach often employs the comparative sequential method, defined as the "systemic comparison of two or more historical sequences." ${ }^{28}$ Max Weber's The Protestant Ethic and the Spirit of Capitalism (1905) and Barrington Moore's Social Origins of Dictatorship and Democracy (1966) are classic examples of the comparative sequential method. ${ }^{29}$ Historical institutionalists often analyze a small number of cases and focus on rich descriptive data that emphasize the role of institutions in structuring behavior. ${ }^{30}$ Historical institutionalism need not always be cross-national in scope, but comparison-be it cross-national or national-provides a tool for demonstrating how specific political events and decisions are construed and structured. Comparative historical institutional analysis is well suited for studying the interaction between institutions and policy choices. It can help explain not only the causal relationship between $X$ and $Y$, but also the mechanisms through which $X$ affects $Y$. Historical institutionalist analysis is also quite adept at explaining political events and circumstances within a small set of countries or polities (internal validity), although it tends to lack generalizability or external validity. When making small- $N$ comparisons using historical institutionalism, the circumstances are context dependent and unique to the specific institutional environment within a particular country, thus one would have to make a large leap to generalize their results to a larger set of countries. Finally, the robustness of this

27. William Faulkner, Requiem for a Nun (New York: Vintage, 2011), 23.

28. James Mahoney and Tulia G. Falleti, "The Comparative Sequential Method," in Advances in Comparative-Historical Analysis, ed. James Mahoney and Kathleen Thelen (Cambridge, U.K.: Cambridge University Press, 2015), 211-39, at 211.

29. Other studies using the comparative sequential method include Sven Steinmo, Taxation and Democracy (New Haven, Conn.: Yale University Press, 1996); Sven Steinmo and Caroline J. Tolbert, "Do Institutions Really Matter? Taxation in Industrialized Democracies," Comparative Political Studies 31 (1998): 165-87; Peter J Katzenstein, Beyond Power and Plenty (Madison, Wisc.: University of Wisconsin Press, 1978); Kathleen Thelen, "Historical Institutionalism in Comparative Politics," Annual Review of Political Science 2 (1997): 369-404; Theda Skocpol and Paul Pierson, "Historical Institutionalism in Contemporary Political Science," in Political Science: State of the Discipline, ed. Ira Katznelson and Helen V. Milner (New York: W.W. Norton, 2002), 693-721.

30. Sven Steinmo, Kathleen Thelen, and Frank Longstreth, eds., Structuring Politics: Historical Institutionalism in Comparative Analysis (Cambridge, U.K.: Cambridge University Press, 1992). 
type of approach stems from its reliance on "macroconfigurational explanations, its emphasis on deep case-based research, and its attention to process and the temporal dimensions of politics." ${ }^{31}$ Historical case study research can provide explanations for how and why certain outcomes and interactions unfold, given a specific context and timing. This is significant for furnishing causal explanations for large-scale social phenomena such as the foundation of the welfare state.

Italy is an excellent setting for analyzing how divergent behavioral paths follow from institutional differences within a single territory and a unitary political system. In the following sections, I provide a causal explanation of the institutional settings in which these divergent taxpayer behaviors were formed, beginning with Italian unification in the nineteenth century and finishing with the start of the Second Republic in the 1990s. The reasons for choosing to begin with unification are threefold. First, beginning with unification, rather than with thirteenth-century Italy, allows for a more thorough and deeper analysis of the development of the links among events, institutions, and behavior. Second, unification-the first major institutional punctuation in modern Italian history-had significant structural and economic consequences for the South, and hence important behavioral implications. Finally, unification provided a uniform tax and political system across Italy for the first time, and thus sets the stage for North-South comparisons.

\section{Church-State Relations since the Risorgimento}

In this section, I argue that the often conflictual relationship between the Catholic Church and the state, as well as how that conflict unfolded in Northern and Southern Italy, defined two separate attitudes regarding political unification, and hence toward the state. While Southerners perceived the Catholic Church as a source of protection against foreign occupying forces from the North, Liberal Democrats who favored the national state expropriated a disproportionate amount of taxes from the South to fund public investment in the North. This led Southern individuals to seek ways to avoid paying taxes that they saw as illegitimate. ${ }^{32}$ By contrast, Northern citizens were more likely to pay taxes, since the state would spend that money in ways that benefited them.

31. Ibid., 28.

32. Denis Mack Smith, Modern Italy: A Political History (Ann Arbor: University of Michigan Press, 1997) 81; Nick Carter, Modern Italy in Historical Perspective (London: A\&C Black, 2010), 211. 
The unique position of the Church, geographically and historically, has influenced political processes and citizens' attitudes towards taxation, as well as their confidence in public institutions, by providing moral authority on political and social issues. Indeed, for Catholics the relationship between the Italian state and Vatican City, a recognized independent state surrounded by Italy, creates a conflict between loyalty to the state and devotion to the Church. The Risorgimento (Resurgence), a period of political consolidation in Italy from 1815-1871 that culminated in national unification, led to several papal documents that intensified the conflict between the Church and the state. Unification ushered in a new form of civic duty which demanded loyalty to a nation-state that embraced political and economic liberalism, challenging the Church's monopoly on institutional obedience. Pope Pius IX's 1864 Syllabus of Errors and Pope Leo XIII's 1891 Rerum Novarum both reflect the assumption that the Church was the center of societal prosperity and private and social life. The two documents were as political as they were doctrinal. The Syllabus of Errors presented the Vatican's rejection of liberal democratic principles and, therefore, of the newly unified Italy. The book rejects the notion that the Pontiff should uphold freedom of speech, freedom of the press, and freedom of religion, and forbids Catholics from subscribing to them. ${ }^{33}$ Pope Leo XIII legitimized the avoidance of unfair taxes in the Rerum Novarum and in his discussion of fair wages:

The right to possess private property is derived from nature, not from man; and the State has the right to control its use in the interests of the public good alone, but by no means to absorb it altogether. The State would therefore be unjust and cruel if under the name of taxation it were to deprive the private owner of more than is fair. ${ }^{34}$

While this clash between church and state played out throughout Europe and significantly influenced individual attitudes and behavior regarding taxation, ${ }^{35}$ it was most evident in Italy, the home of both the Holy See and reformers determined to unify a divided nation. For a half century the Vatican posed the greatest obstacle to a unified Italy, and this generated a tremendous amount of cognitive

33. Ibid.

34. Pope Leo XIII, Rerum Novarum, Encyclical Letter on the Condition of Labor, 1891, at article 47.

35. Sven Steinmo, The Fiscal Foundations of the State: Taxation in Europe and America (under contract with Oxford University Press). 
dissonance among the Italian people. Although his temporal power was greatly reduced, the Pope sought to assert influence through spiritual decree. In what was considered to be one of the most controversial aspects of his papacy, between 1861 and 1869, Pius IX declared himself infallible, denounced the newly unified state as incompatible with Catholicism and, with its policy of non expedit ("it is not expedient"), declared that any political participation-be it holding public office or voting - was an unacceptable form of support for the illegitimate state. Since most Southerners were illiterate and hence ineligible to vote anyway, this policy did not drive them away from the Church. Moreover, although the Church's policy did not prohibit tax paying, it did help citizens rationalize not paying taxes to the state.

In 1870, the Italian army first conquered Rome, the center of the Papal states, generating greatly varied attitudes between North and South. Southerners saw the Church as not only a barrier between them and Northern occupation, but also as a guarantee of semi-autonomy. Although there was a large anti-clerical movement in the North, the relationship between Catholicism and citizens was considerably different in the South. Sabetti describes the clerical system in Southern Italy as far less hierarchical than that in the North. ${ }^{36}$ Southern dioceses had more limited resources and fewer parishes than their Northern and Central counterparts. ${ }^{37}$

Southern Italians therefore viewed the Church as a more democratic institution than, in the words of Sabetti, the "rapacious landlords, tax collectors, conscription officers and police officials" of secular civil society. ${ }^{38}$ Saunders describes the spirit of the South "as a form of practical wisdom, a fountain of energy for social transformation, a domain of autarky and of resistance to domination, but also as ignorant superstition, debilitating fatalism and futility, a source of social divisiveness, and anarchism." ${ }^{39}$ All of this suggests a climate of self-sufficiency in the South despite political unification.

State land reclamation largely displaced the Church in Southern Italy, increasing Southern disaffection towards the state. In fact, by 1880 over a million acres of ecclesiastical lands had been dispossessed by the state and sold. ${ }^{40}$ The disestablishment of Church lands led to private individuals, usually wealthy land owners, exploiting the collective for private gain, which led to a large expansion of a me-

36. Sabetti, Search for Good Government, 231-32 (see note 11 above).

37. John Pollard, Catholicism in Modern Italy: Religion, Society and Politics Since 1861, (New York: Routledge, 2008), 11.

38. Sabetti, Search for Good Government, 232 (see note 11 above).

39. Ibid., 185.

40. Smith, Modern Italy, 82 (see note 32 above). 
diatory class known as the mafia. ${ }^{41}$ The mafia was even known to extract taxes from priests for saying mass. ${ }^{42}$

Unification thus greatly structured the relationship between citizens, church, and state, producing two separate tax compliance environments. In the South, where the state was absent except as tax collector, citizens turned away from the state and towards the Church, generating a low-compliance environment. ${ }^{43}$ But in the North, where literacy rates were high and many had the right to vote, non-expedit drove citizens away from the Church and made them more likely to support the state through higher tax compliance.

In addition, the South paid a disproportionally high amount of taxes; it made up only $27 \%$ of GDP, but $32 \%$ of the tax base, while the North generated $48 \%$ of the national wealth and paid only $40 \%$ of the nation's taxes. ${ }^{44}$ Due to a much larger agricultural base in the South, higher taxes on grain disproportionally affected the South, while the North benefited the most from public spending. In addition, since bread was a staple of the Southern Italian diet, increased taxes on grain also hit Southern peasants the hardest. ${ }^{45}$ As Clark notes, the state imposed an unprecedented tax burden in the South at the time of unification, which funded the development of the North. ${ }^{46}$ The North's political dominance meant that it controlled decisions about taxation and public spending, which favored citizens in the North and extracted important resources through taxation from the South, exacerbating the North-South economic divide. Between 1862 and 1897, 455 million lire were spent on landfills in Northern and Central Italy, while only 3 million were spent on such resources in the South. The majority of school and railway spending was also concentrated in the North. ${ }^{47}$ Development in the South certainly

41. James Walston, The Mafia and Clientelism: Roads to Rome in Post-War Calabria (London: Routledge, 1988).

42. Smith, Modern Italy, 213 (see note 32 above).

43. For an explanation of different compliance environments see Marcelo Bergman, Tax Evasion and the Rule of Law in Latin America: The Political Culture of Cheating and Compliance in Argentina and Chile (State College: Pa.: Pennsylvania State Press, 2010).

44. Smith, Modern Italy (see note 32 above).

45. Carter, Modern Italy (see note 32 above).

46. Martin Clark, Modern Italy 1871-1995 (New York: Longman, 1996), 24. However, Carter argues that the evidence does not support claims of exploitation and high taxation on Southerners at the turn of century; see Carter, Modern Italy, 50 (see note 32 above). Most accounts agree with Clark; see, for example, Antonio Gramsci, Selections From the Prison Notebooks of Antonio Gramsci, ed. Geoffrey Nowell-Smith and Quintin Hoare (New York: International Publishers, 1971), 70-71, 94; Sidney Tarrow, Peasant Communism in Southern Italy (New Haven, Conn.: Yale University Press, 1967), 21-26.

47. Martin Clark, Modern Italy, 25 (see note 46 above). 


\section{4 | Divided Nation}

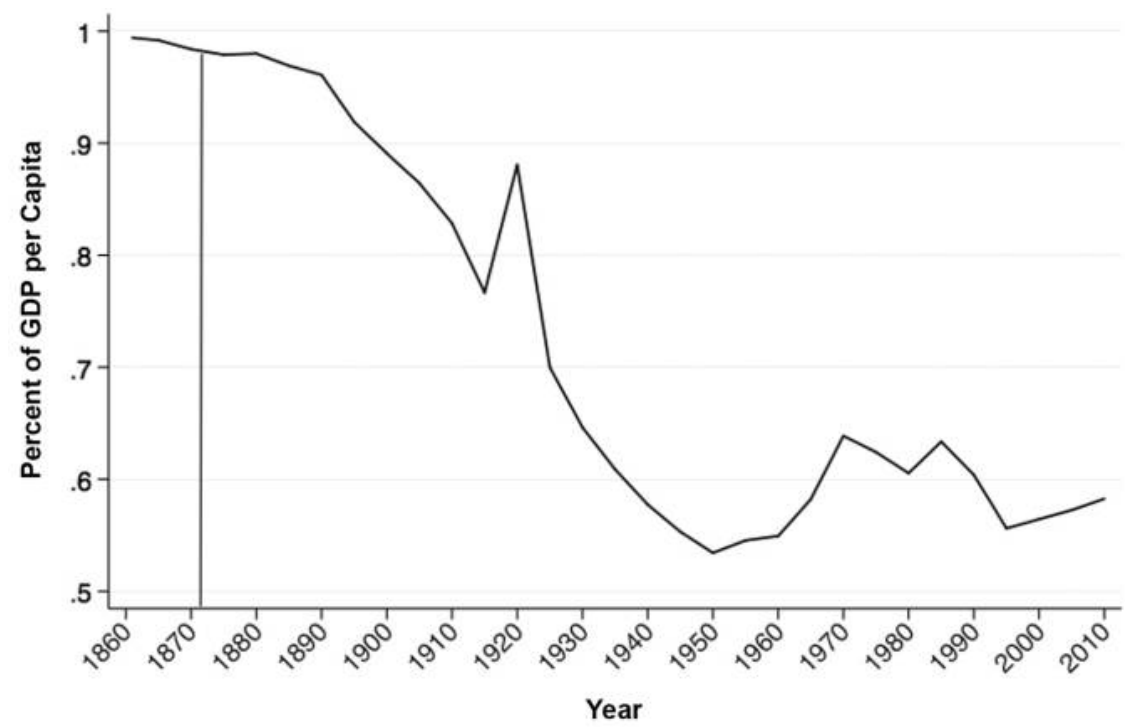

Figure 3. GDP Per Capita in the South as a Percent of Northern GDP Per Capita Note: The vertical line demarks unification.

Source: L. Bianchi, et al. "150 Anni di Crescita, 150 di Divari: Sviluppo, Trasformazioni, Politiche," Rivista Economica del Mezzogiorno 3 (2011): 449-516.

suffered after unification, and as a result, so did Southerners' relationship to the newly formed state. See Figure 3 for an illustration of the rapid decline in Southern per capita income as a percent of Northern per capita income after the Risorgimento. These differences in economic development, investment, and taxation led to a sense of unfairness and distrust in the South, and hence to less willingness to pay taxes. ${ }^{48}$

In sum, the relationship between Italy's most important institutions, the Catholic Church and the State, put the newly unified country on two different trajectories that shaped the Northern and Southern Italian experience with the state and their public institutions. The North expropriated a disproportionate amount of taxes from South and used the money to fund its own public investments, promoting uneven development in Italy and a deep distrust in the state among Southerners. Because the state lacked the political will to govern and redistribute goods efficiently in the South, citizens were more likely to pursue other means of

48. James Andreoni, Brian Erard, and Jonathan Feinstein, "Tax Compliance," Journal of Economic Literature 36 (1998): 818-60. 
redistribution, such as an individualized type of clientelism that either provided financial favors to the Southern elite or public employment and benefits to individuals, as we will see in the following sections. By contrast, Northern citizens were more likely to pay taxes because they believed the state would spend their money efficiently.

\section{The Italian People's Party, the Italian Socialist Party and the Rise of Fascism}

The turn of the century brought rising fears of socialism throughout Europe. Hence, the Catholic Church and right-wing liberals joined forces in the North, where there was a strong industrial labor base, to organize mass political engagement in direct competition with the socialists. Catholic, right-wing, and socialist organizations made conscious efforts to build effective and efficient public institutions in order to garner support for their political movements; these institutions promoted a high-compliance environment. On the other hand, the South, made up of mainly peasants, lacked any kind of industrial base and became disengaged with civic and associational life, leading to a low-compliance environment.

Although Putnam describes a long history of associational behavior (civicness) in the North, dating back to the republican governments of the Middle Ages, the Catholic Church after the turn of the century made a conscious effort to build civic associations as an alternative to a Socialist workers' movement. This played an important role in driving civic consciousness and institutional development in Northern and Central Italy in the years immediately after World War I. By contrast, the lack of any significant industrial labor force in the South hampered political competition and inhibited the formation of efficient public institutions or a civic oriented populace. Tarrow argues that at the time of unification, "so ingrained was the clientele system that the mass of new voters, most of them rural and all of them dependent economically on the political elite, were easily integrated into the existing system." ${ }^{49}$ In other words, rather than having a political choice, poor Southern peasants became dependent on their clientelistic relationships with local elites. The provision of individualized goods from patrons to clients inhibited the foundation of a civically oriented populace.

The rise of a Catholic political party (the Italian People's Party, Partito Popolare Italiano) after 1914 marked the beginning of Catholic mainstreaming in Italian politics and challenged the dominance of the ruling party in the North.

49. Tarrow, Peasant Communism in Southern Italy, 168-69 (see note 46 above). 
Because the state had almost completely dismantled organized Catholicism in the South in the early twentieth century, support for the Italian People's Party came mainly from the Northern regions of Italy. Pope Benedict XV, Pope Pius's successor, immediately reversed his predecessor's anti-modernization policies, such as banning Catholic trade unionism, while improving the Church's relationship with the Italian government and the Italian people. While anti-Italian stigma had been attached to the Catholic Church since the Risorgimento, Italian-Catholic politicians and the patriotism of the Catholic clergy during the war changed the prevailing feelings about Catholicism in Italy, ${ }^{50}$ which bitterly divided the old ruling class and paved the way for outside parties such as the People's Party and the Socialist Party (Partito Socialista Italiano). These two parties took a combined total of more than half of the legislative seats in the election of 1919. Only in the South did the "old government" parties (Liberal Democrats, Partito Liberale Democratico) win more than half the votes. This was largely the result of the practice of trasformismo, in which ruling parties won over the opposition party in return for political, and often financial, favors. The old guard liberals, especially in the South, made use of public resources for both individual and political gain. ${ }^{51}$

Political strife in Italy only further divided the North and South along party lines. As a result of this election, 146 of 156 of the Socialist deputies came from the North and Center; 76 of the 100 People's Party deputies were also from the North; and 162 of the 239 deputies from the Liberal Party and the Radical Party, who had previously dominated the parliament, were elected in the South. Although the 1919 election resulted in the first "Radical" government led by Francesco Nitti, political turmoil between the Radicals, Socialists, and Fascists led to Nitti's resignation and the return of the Liberal Democrat Giolitti as prime minister in 1920. When elections were called again in 1921, the Giolitti government's hegemony was tenuous. To solidify his control, he made certain concessions to the Fascists, including adding them to the government's party list. The disparate governing coalition Giolitti put together was doomed from the outset, and resulted in his immediate resignation, to be followed by a string of shortlived prime ministers and the eventual rise of Fascist leader Benito Mussolini.

In sum, the early twentieth century in Italy was marked by deep divisions between the Church and the state, among political parties, and between the North

50. Pollard, Catholicism in Modern Italy (see note 37 above).

51. Walston, The Mafia and Clientelism, 49 (see note 41 above). 
and the South. These divisions were economic as well as political. Political parties competed for the burgeoning industrial labor movement in the North by providing and building effective public services and institutions. The South, on the other hand, was ruled by the old ruling partly (Liberals), who enjoyed a large monopoly on political power. By providing public jobs and financial favors to the landed elite through trasformismo, the ruling party maintained its hegemony in the South, marginalizing Southern citizens from the political process.

\section{The Fascist Period (1922-1943)}

The Fascist period can be characterized by two main approaches to building effective administrative capabilities and public services across Italy: an attempt to modernize the tax system with a series of uniform tax reforms, and a series of pubic investments that had the unintended effect of increasing the North-South economic cleavage. To dampen some of the more negative consequences of the administration's policies, the government funneled money through quasi-state organizations, strengthening clientelism in the South. This hardened the lowcompliance environment in the South.

Tax reform during the Fascist period involved three separate methods. The first, liberal tax reform in the early Fascist period (1922-25), provided preferential tax treatment to productive industries with the misguided expectation that these industries would then comply with existing tax law. After this reform failed, Mussolini shifted to an authoritarian model, where he would stigmatize and penalize evaders. He declared tax evaders "the worst parasites in the nation" and increased tax enforcement between 1926 and 1929, while introducing tax verification agents and criminalizing tax evasion. ${ }^{52}$ However, the corporatist economic model and increased foreign commitments, such as the Italian-Ethiopian War in the 1930s, which diverted administrative resources, led him to restrain the more authoritarian aspects of the administration's tax policy, which demanded a large amount of administrative oversight. This led the administration back to the more liberal, cooperative model enforced during the 1922-25 period, especially with respect to businesses.

Although tax and administration reform are important aspects of any successful attempt to increase tax compliance, Mussolini's complete disregard for the South exacerbated the economic divisions between the North and South and

52. Stefano Manestra, "A Short History of Tax Compliance in Italy," Bank of Italy Occasional Paper 81 (2010), at http://dx.doi.org/10.2139/ssrn.1825982. 
hence the differences in their tax compliance environments. Economic asymmetries and disproportional public investment generate a feeling of unfairness and distrust in the economic system, both of which reinforce the low-compliance environment. ${ }^{53}$ Mussolini's industrial policy accentuated economic divisions between the North and the South by concentrating economic development in engineering, steelmaking, chemicals, and hydro-electricity supply-all industries located in the industrial triangle of the Northwest. Almost half of industrial workers and two-thirds of engineers worked in Lombardy, Liguria, and Piedmont, while the majority of workers from the South were farmers and artisans. ${ }^{54}$ The government also increased the extent of the welfare state in the Fascist period, making Northern industrial workers eligible for generous benefits not available to Southern workers-an imbalance that continues to this day. Because of the North's large industrial base, unionized workers were able to lobby for and win larger pensions than the average Southern Italian peasant. This contributed to patronage and clientelistic practices as a means of income supplementation in the South; clients directly exchanged their votes for public employment and favorable tax treatment. ${ }^{55}$

Moreover, Mussolini's push to project Italy as an international power had adverse consequences for the Southern economy. Mussolini implemented a revaluation of the lira in 1926 to project Italy's position, which reduced wages and sharply increased unemployment, largely in the agricultural South. In the late 1920s through the early 1930s, Mussolini increased tariffs on wheat, which amounted to a large concession to landowners, who gained the most from the government policies, whereas Southern peasants were hit the hardest. ${ }^{56}$ To lessen the damage in the South, the administration funneled jobs through parastato, quasi-governmental agencies which dealt with health, welfare, and pensions, which then became the most important criterion for resource distribution. ${ }^{57}$

Fascism only enlarged the economic and social disparity between the North and the South, resulting in completely different encounters with the state in the two regions. The Northern experience was shaped by public investment and efficient public institutions. Indeed, Fascism was born and maintained in the North,

53. Andreoni et al., "Tax Compliance" (see note 48 above).

54. Clark, Modern Italy 1971-1995 (see note 46 above).

55. Maurizio Ferrera, "The 'Southern Model' of Welfare in Social Europe," Lournal of European Social Policy 6 (February 1996): 17-37.

56. Peter Neville, Mussolini (New York: Routledge, 2014); Clark, Modern Italy 1971-1995 (see note 50 above).

57. Walston, The Mafia and Clientelism (see note 41 above). 
though it did eventually conquer the South. ${ }^{58}$ In the South, distrust and contempt for the state increased due to the state's general neglect of that region.

\section{From the First Republic to the Second Republic (1946-1994)}

The period after World War II brought great, but asymmetric, prosperity in Italy. Just as during the previous period, political competition among the Christian Democrats, the Socialists, and the Communists (Partito Communista Italiano) led to major public works and investment in Northern Italy, while the Christian Democrats' political monopoly intensified clientelistic networks. Although the central government invested heavily in the South beginning in 1950 with a Fund for the South (the Cassa per il mezzogiorno), the implementation of the fund was greatly affected by clientelism. In 1970, regional governments were implemented, further exacerbating the underlying issues in the South. Regional governments were granted more autonomy and discretion in the distribution of resources, especially financial resources, which they then could funnel to private interests. While clientelism became stronger in the South as a result, one of the largest corruption scandals in Italian history unfolded in the North. Widespread distrust in the governing parties hence brought down the government and led to the Second Republic.

After World War II, Italian citizens were polarized both economically and ideologically. In the 1944-46 period, Sicilian farmers organized to secede from the North, which led to a June 2, 1946, popular vote pitting the Italian dynasty (the Monarchy ruled by Humbert II of Savoy) against the Republic. The North, led by the Communists, Socialists, and Christian Democrats, favored the Republic; the majority of the South voted to uphold the dynasty. ${ }^{59}$ In 1946 tensions between the Communists and the Christian Democrats presented another challenge to national unity: while the Communist Party was closely tied to the Soviets, aid and investment from the U.S. government and U.S. firms influenced the Christian Democrats and the Alcide De Gasperi government.

Italian policy after the war had to address funding public investment for a newly developed country. The new Republic therefore implemented broad tax reform on January 11, 1951, under the control of Finance Minister Enzio Vanoni. The law had four major provisions: 1) annual tax returns required of all tax-

58. John Pollard, The Fascist Experience in Italy (London: Routledge, 2005).

59. Ibid.; See also David Gilmour, The Pursuit of Italy: a History of a Land, Its Regions, and Their Peoples (New York: Macmillan, 2011). 
payers, both employees and self-employed; 2) greater progressivity combined with lower income taxes overall; 3) a series of consumption taxes; and 4) business taxes on items such as stamps and licensing. ${ }^{60}$ Unfortunately, subsequent administrations lacked the administrative capacity to continue through with Vanoni's reforms, and tax compliance remained low. The new tax code was particularly susceptible to favoritism, especially among high-income earners as well as specific Christian Democratic voting blocs in the South. In addition to tax reform, the government invested in the Northern industrial triangle, while continuing to leave the South economically behind. ${ }^{61}$ The 1950 s marked the beginning of approximately two decades of great prosperity in Northern Italy. As it became one of the most industrial regions in Europe, greatly benefiting from the European Community, the Marshall Plan loans, and an influx of cheap Southern labor, the South remained impoverished. Data provided by Clark depict Southern Italy in the 1950s as similar to many underdeveloped countries. ${ }^{62}$ The disparities between the North and the South were so considerable and evident that the state instituted the Fund for the South-a rural spending agency providing roads, housing, and water to rural areas.

Established in 1950, the Fund's original strategy related primarily to agricultural production, but by 1957 it had been transformed to favor the relatively capital-intensive steel, chemical, and petrochemicals industries, while perpetuating a mass patronage system in the South. It increased unemployment among Southerners by shifting investment from the agricultural periphery to the urban coastlands and importing highly skilled workers from the North to the South. ${ }^{63}$ And although Amintore Fanfani, De Gasperi's successor, hoped to replace the deeply embedded clientele system with a new form of organized politics in the South, none of his state intervention plans disrupted the clientele system. ${ }^{64}$ According to Chubb, the Fund became "a political bandwagon for the maintenance of local clienteles." ${ }^{65}$ Tarrow disparages both the Fund and the National Hydrocarbons Agency, calling them "far from revolutionary . . . mainly a program of mass patronage, which could gather votes for the party from all groups and

60. Christina Amrosetti, Ezio Vanoni e la Riforma Tributaria in Italia, SIEP Working Paper 325 (Pavia, Italy: Università de Pavia, 2004).

61. Clark, Modern Italy 1871-1995, 349 (see note 46 above).

62. Ibid., 357.

63. Judith Chubb, Patronage, Power and Poverty in Southern Italy (Cambridge, U.K.: Cambridge University Press, 1982).

64. Tarrow, Peasant Communism in Southern Italy (see note 46 above).

65. Chubb, Patronage, Power and Poverty in Southern Italy, 32 (see note 63 above). 
shades of opinion in the South." ${ }^{16}$ In Calabria, from 1950 to 1976, all the directors of the Fund's main office were Christian Democrats. ${ }^{67}$ According to Duggan, these bureaucrats considered the public sector to be a tool to garner partisan political support, instead of a means to develop the South or to foster what he calls an "ethical model of citizenship."

This form of clientelism in the South stymied citizen cooperation. Mario Caciagli argues that clientelism is a cultural phenomenon and a unique form of political culture defined by reciprocity and deference. ${ }^{69}$ The resilience and path dependency of institutions contributed to the tenacity of clientelism in the Southern Italian political system. ${ }^{70}$ An inefficient and asymmetric economic structure reinforced a clientelist system that directly supported the individual interest in income supplementation, while disregarding the public interest. Caciagli argues that "in the conditions of the South, clientelism remained the principal factor in inhibiting a culture of social cooperation and collective action." In other words, clientelism secures lasting political power, but fails to build a civic consciousness or an active civil society. ${ }^{71}$

Moreover, clientelism increased the size of the inefficient bureaucracy in the South, while distributing financial favors to local businesses. In the early 1950s, the South, with only $38 \%$ of the population, accounted for $45 \%$ of all public employees. This number increased to $63 \%$ by 1963 , overwhelmingly driven by clientelistic practices between the Christian Democrats and important interest groups. ${ }^{72}$ Although staffing the public bureaucracy was one feature of their clientelistic network, Warner writes: “The [Christian Democrats'] clientelist system grew not so

66. Tarrow, Peasant Communism in Southern Italy, 313 (see note 46 above).

67. Carolyn M. Warner, "Mass Parties and Clientelism: France and Italy," in Clientelism, Interests, and Democratic Representation, ed. Simona Piattoni (Cambridge, U.K.: Cambridge University Press, 2009), 122-51.

68. Christopher Duggan, The Force of Destiny: a History of Italy Since 1796 (New York: Houghton Mifflin, 2007), 56-63.

69. Mario Caciagli, "The Long Life of Clientelism in Southern Italy," in Comparing Political Corruption and Clientelism, ed. Junichi Kuwata (Hampshire, U.K.: Ashgate Publishing, Ltd., 2006), 157-70.

70. Sven Stienmo, "Historical Institutionalism," In Approaches and Methodologies in the Social Sciences, ed. Donatella della Porta and Michael Keating (Cambridge, U.K.: Cambridge University Press, 2008): 118-138; Paul Pierson, "Increasing Returns, Path Dependence, and the Study of Politics," American Political Science Review 94 (2000): 251-67.

71. Caciagli, "The Long Life of Clientelism" (see note 69 above).

72. Warner, "Mass Parties and Clientelism," 130 (see note 67 above). Calculations are from data provided in Pasquale Saraceno, "La Disoccupazione Italiana e' Dovuta a Ragioni Strutturali," in L'Economia Italiana, ed. Augosto Graziana (Milan, Italy: Mulino, 1972), 100-103. 
much from staffing the public bureaucracies under its control, but from distributing the financial largesse of which the state agencies were in possession, and from bureaucratic problem solving on behalf of individual constituents." ${ }^{273}$

Clientelism is not a homogenous phenomenon; rather, it acclimates to a specific political and economic environment. On the one hand, in the South, where resources were extremely scarce and interest groups were not visible, the Christian Democratic political machine dealt with individual constituents by promising universal benefits and resource distribution. Local elites in the South had little interest in developing the Southern economy, as they benefitted greatly from their networks. The low tax compliance environment in the South was perpetuated by those clientelistic networks. Patrons could represent their clients through the distribution of tax favors or by their willingness to turn a blind eye to tax evasion. ${ }^{74}$ The state, which deferred much of its administrative responsibilities, such as tax collection, to local notables, demanded very little from its citizens. ${ }^{75}$

Although clientelism took on a particularly detrimental form in the South, funneling jobs and public resources to individual clients, in the North clientelism evolved in a way that actually increased public investment and citizen engagement. In the North, where interest groups such as Catholic Action and the Communist Party were firmly rooted in the political ecosystem, the Christian Democrats had to appeal to local leaders with specific benefits, usually in the form of public works. Unlike in the South, active political competition between the Communists and the Christian Democrats for a politically powerful industrial base forced the parties to provide public works effectively, while at the same time encouraging active political participation. The state and civil society (labor unions) worked hand-in-hand to develop the North's economy. In fact, Tarrow contends that it was the pro-labor actors in the North, such as the Christian Democrats and Catholic Action as well as the Communist and Socialist parties, that guaranteed the "defense of democracy and of social development" and that deliberately established civic associations, and hence good governance. ${ }^{76}$ In the South, hierarchical links were more common between the political and landed elites and peasants, while in the North, the state and civil society (mainly unions) worked cooperatively to invest in large scale public works projects, as well as in industrial firms.

73. Ibid., at 141.

74. Duggan, The Force of Destiny (see note 68 above).

75. Jonathan Hopkin and Alfio Mastropaolo, "From Patronage to Clientelism: Comparing the Italian and Spanish Experiences," in Clientelism, Interests, and Democratic Representation, ed. Piattoni, 152-71, at 155 (see note 67 above).

76. Tarrow, "Making Social Science Work" (see note 11 above). 
As I argued above, when the state lacks the capacity to govern and redistribute goods efficiently, citizens will often pursue other means of redistribution, including the more individualized form of clientelism found in the South. ${ }^{77}$ By contrast, citizens are more likely to pay taxes if they believe their tax money is being spent efficiently. ${ }^{78}$ For Southerners, the government, beginning with unification, was inefficient and taxation was relatively high. Thus, clientelism provided a vehicle to sidestep the inefficiencies of the state and avoid high taxation. The Christian Democrats' clientelistic political strategy guaranteed its national political dominance for nearly 40 years. Even in the most Northern areas-where the Communist Party maintained a great deal of strength - the Christian Democrats' use of clientelistic politics in the form of business regulations and lax tax enforcement broadened its support. ${ }^{79}$

When the governing coalition incorporated the Socialist Party in 1963, the Italian welfare system moved in an ambitious direction, unintentionally bolstering clientelistic ties, especially in the South. A massive amount of state funds was invested in the South, largely fueling its existing clientistic networks and increasing the scope of clientelism by providing more benefits to more citizens in the South. Between the mid-1950s and the beginning of the 1970s, welfare became the largest central government expenditure, reaching $38 \%$ by the mid-1970s. ${ }^{80}$ Welfare spending became a tool by which patrons could distribute benefits directly to individuals (individual-level clientelism), ${ }^{81}$ such as the approval of unemployment benefits, through the welfare state to a vast network of clients, in exchange for individual votes. This type of clientelism is particularly prevalent

77. Valeria Fargion, "Social Assistance and the North-South Cleavage in Italy," in Southern European Welfare States, ed. Martin Rhodes (London: Routledge, 1997), 135-54; Bergman, Tax Evasion and the Rule of Law in Latin America (see note 43 above); Hopkin and Mastropaolo, "From Patronage to Clientelism" (see note 75 above).

78. Cummings et al., "Tax Morale"; Edlund, "Trust in Government and Welfare Regimes"; Frey and Feld, "Deterrence and Morale in Taxation"; Frey and Torgler, "Tax Morale and Conditional Cooperation"; Levi, Of Rule and Revenue; Pommerehne, Hart, and Frey, "Tax Morale, Tax Evasion"; Scholz and Lubell, "Trust and Taxpaying" Smith and Stalans, "Encouraging Tax Compliance"; Torgler, Benno and Schneider, "Shadow Economy" (see note 19 above for all of these sources). See also Kent Smith, "Reciprocity and Fairness: Positive Incentives for Tax Compliance," in Why People Pay Taxes: Tax Compliance and Enforcement, ed. Joel Slemroad (Ann Arbor: University of Michigan Press, 1992), 223-50.

79. Hopkin and Mastropaolo, "From Patronage to Clientelism" (see note 75 above).

80. Maurizio Ferrera, "Italy," in Growth to Limits: ed. Peter Flora (New York: Walter de Gruyter, 1986), 385-482.

81. This contrasts with categorical-level clientelism, in which benefits, such as public works projects, are provided to the client (such as a union or professional organization) in return for the collective votes of that organization's members. 
Table 3. The Distribution of Executive Board Positions on the Social Security Fund by Party, 1945-75

\begin{tabular}{|c|c|c|c|c|c|c|}
\hline Political Parties & $1945-47$ & $1948-54$ & $1955-62$ & $1963-69$ & $1970-75$ & $\begin{array}{c}\text { Total } \\
(1945-1975)\end{array}$ \\
\hline Christian Democrats (DC) & 25.1 & 31.5 & 35.7 & 38.0 & 38.5 & 36.3 \\
\hline \multicolumn{7}{|l|}{ Italian Communist } \\
\hline Party (PCI) & 8.7 & 5.3 & 4.0 & 4.1 & 4.1 & 4.3 \\
\hline \multicolumn{7}{|l|}{ Italian Democratic } \\
\hline Socialists (SDI) & 6.4 & 6.5 & 7.1 & 5.3 & 4.7 & 5.8 \\
\hline Italian Socialist Party(PSI) & 5.9 & 4.3 & 4.2 & 5.4 & 8.4 & 5.6 \\
\hline Italian Liberty Party (PLI) & 5.0 & 7.2 & 4.1 & 3.5 & 2.3 & 4.0 \\
\hline \multicolumn{7}{|l|}{ Italian Social Movement } \\
\hline Party (neo-fascists) (MSI) & 0.5 & 1.6 & 2.1 & 2.5 & 1.7 & 2.0 \\
\hline Not Identified & 47.5 & 40.1 & 39.3 & 37.6 & 37.0 & 38.5 \\
\hline$(\mathrm{N})$ & (219) & $(2,019)$ & $(3,822)$ & $(4,028)$ & $(3,453)$ & $(13,541)$ \\
\hline
\end{tabular}

Note: "Not identified" refers to officials with no party affiliation or unknown party affiliation. Source: Ferrera, "Italy," 448 (see note 80 in the text above).

in economically disadvantaged areas, where resources (such as jobs) are particularly scarce. ${ }^{82}$ From 1951 to 1976 , the portion of the labor force employed by the state doubled to $22 \%$, which is a sign of both Italy's bureaucratization and a distinctly Southern form of clientelism. ${ }^{83}$ Because these benefits were provided at the individual level, clients would not associate benefits from patrons as a public goods provision, which would then increase tax compliance, but rather as a private good.

We can also examine the distribution of executive board positions on the social security funds by party identification in order to better understand the extent of clientelism in the welfare system. Table 3 clearly shows that the mass patronage system favored the Christian Democrats more than other parties.

Clientelistic markets were reinforced when individuals from weak economic sectors (small enterprises, services, and agriculture) sought out ways to supplement their income as a result of Italy's inequitable welfare system. Italy's two-tier welfare system distinguishes between a highly protected class of worker (mainly industrial workers and public employees) and those in weak sector employment

82. Warner, "Mass Parties and Clientelism," 125 (see note 67 above).

83. Ibid., 395. 


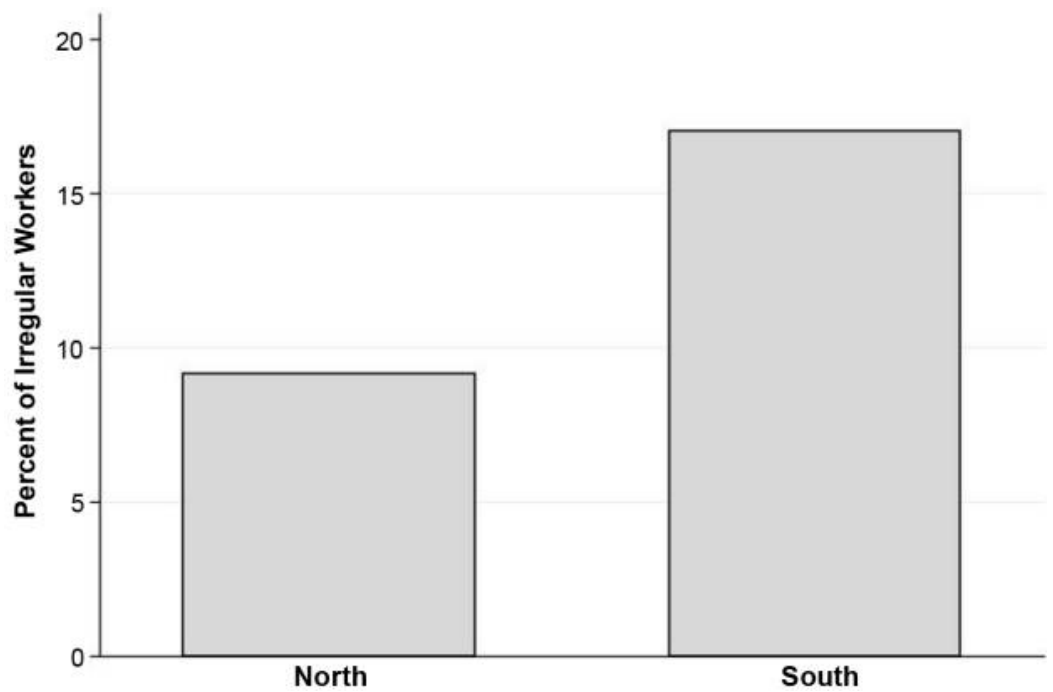

Figure 4. Differences in Underground Employment by Region

Note: The $y$-axis shows underground work as a percentage of total full-time equivalent work. Source: Chiarini and Marzano, "Structural and Cyclical Patterns" (see note 3 in text above).

(small enterprises, services, agriculture, and gray or black market jobs), who receive far fewer benefits. Although the South accounted for a disproportionate number of public sector jobs, the majority of Southerners still worked in weak sector employment throughout the 1960s and 1970s. As seen in the large regional discrepancies in irregular employment (see Figure 4), the two-tier system benefited Northern workers much more than their Southern counterparts. Southerners supplemented their insufficient incomes by subverting the rules and regulations of the welfare system as well as by evading taxes, and public administrators tolerated and even encouraged them. ${ }^{84}$

In the 1960s, the government introduced a major public investment program that helped to raise the standard of living throughout the South, but this period also was characterized by a significant amount of political turmoil, which exacerbated citizens' disaffection towards the state. By 1967, the Italian economy was showing signs of crisis. The large-scale migration of unskilled Southern workers had supplanted high-skill factory workers in the North, which led to major factory floor protests throughout Northern Italy. Then, factory workers in the South

84. Maurizio Ferrera, "The Uncertain Future of the Italian Welfare State," West European Politics 20 (December 1996): 231-49. 
took to the shop floors to demand better pensions, social security, housing, and health services. By 1976, the trade union movement had become a major force in Italian politics, representing nearly $50 \%$ of workers ${ }^{85}$ Large pay raises, however, increased overall labor costs in Italy to levels exceeding many European countries, and corporate profits suffered by the end of the decade. ${ }^{86}$ Both the extreme right and left responded to the crisis with political terrorism, including assassinations and kidnappings. The major political strife of the 1960s demanded a major political response, and thus the government introduced regional governments with increased autonomy, especially regarding the allocation of welfare spending, in the spring of 1970. By the mid-1970s, Italy's regional governments could provide subsidies, fund and staff welfare agencies, draw up regional development plans, and organize their own cooperatives. However, as Clark writes, these regional governments also fed the Calabrian Mafia (ndrangheta) and the Neapolitan Mafia (camorra), with powerful interest groups supporting particularism rather than creating more efficient, democratic institutions. ${ }^{87}$

Furthermore, in 1973 Finance Minister Luigi Preti introduced tax reforms that aimed to meet the demands of a developed nation and address the burgeoning public deficit. But despite his efforts, the tax system failed to address the underlying administrative or the structural problems, such as clientelism. The new taxes included the establishment of a national progressive income tax, a corporate income tax, a local income tax, a capital gains tax, and a value added tax.

In an attempt to crack down on tax evasion stemming from the large patronage system, the state reverted to the more authoritarian measures Mussolini had used to enforce tax compliance. The state coordinated with provincial newspapers throughout Italy to publish the names of 200,000 tax evaders between 1979 and 1981. Law 516/1982, called the "handcuffs for evaders," elevated the penalties for tax evasion and made indictment easier. ${ }^{88}$ However, these efforts did little to reduce tax evasion. The courts found many of the provisions of the handcuffs law to be unconstitutional, and only a small fraction of accused transgressors were convicted under it. In addition, the courts became so overwhelmed with cases that their only response was to offer tax amnesty. ${ }^{89} \mathrm{Tax}$ amnesties actually lower compliance by demonstrating a lack of enforcement on the

85. Clark, Modern Italy 1871-1995, 377 (see note 46 above).

86. Duggan, The Force of Destiny, 567 (see note 68 above).

87. Ibid., 392.

88. Santoro, L'Evasione Fiscale (see note 2 above).

89. Ibid., at Kindle location 951-52. 
part of the administration. ${ }^{90}$ The less punitive Law 154/1991 and Law 74/2000 replaced the handcuffs law. Income tax evasion actually increased from the time of the implementation of the tax reform through 1978, decreased slightly from 1978 to 1981 , and never fell below $33.7 \%$ in this period. ${ }^{91}$

Despite continuous attempts to fix the tax system, weak administrative capacity and a patronage system entrenched in the political culture of both Northern and Southern Italy ultimately produced tax evasion. In the North, clients were collective actors such as unions and professional associations, who benefited from mass public works projects in return for their members' votes, while in the South, the provision of welfare benefits, public sector jobs, and tax favors characterized the clientelistic system. By the 1980s, the South had been greatly damaged by organized crime, and youth unemployment was nearly 50\%. While Duggan notes that the trappings of modern consumerism had come to the South, he credits cash transfers through the social security system and "superfluous public sector jobs." ${ }^{92}$ In the North, on the other hand, the 1980s was a time of great prosperity. Manufacturing and artisan production were booming, largely due to the state's willingness to overlook tax crimes.

In sum, the 1950s to 1980s brought an enormous increase in development in the North, in some ways fueled by a form of clientelism that funneled resources to efficient and effective public works projects, which in turn were the foundation of a high tax compliance environment. On the other hand, the Christian Democratic political monopoly had little incentive to develop the South, as local political elites were already profiting from an individualized form of clientelism that prioritized personalized interests instead of the public good. This form of clientelism reinforced a low tax compliance environment.

\section{Conclusion}

The culturalist argument proposed by both Banfield and Putnam et al. fails to account for the institutional environment that structures individuals' behavior. This flaw in their theory of civic development in the South leads back to the complex-

90. James Alm, Michael McKee, and William Beck, "Amazing Grace: Tax Amnesties and Compliance," National Tax Journal 43 (1990); 23-37; Andreoni et al., "Tax Compliance," 854 (see note 48 above).

91. Stefano Manestra, A Short History of Tax Compliance in Italy (Rome: Banca d'Italia, 2010).

92. Duggan, Force of Destiny, 575 (see note 68 above). 
ities that this study has sought to address in order to explain tax evasion and compliance. By constructing a historical landscape dating from unification to the fall of the First Republic, I have identified several periods and institutions that have influenced the relationship between state and citizen.

Unification had significant repercussions for the Catholic Church and the newly unified state, defining two divergent patterns of taxpayer behavior. Southern citizens turned to the Church for protection from what they saw as Northern colonizers during this period, while the North embraced calls from liberals for a unified nation-state. The politically dominant North demanded disproportionate revenues from the South to fund public works projects largely benefiting the North, which, I argue, generated greater confidence in the state among Northern Italians and hence a greater willingness to pay taxes. Meanwhile, relative incomes in the South were reduced considerably compared to those in the North (see Figure 3 above); Southerners were exploited by the newly formed state and more supportive of the Church, and thus were more likely to contribute to the Church through the massa commune than to the state through taxation.

During the period directly following unification, from the turn of the nineteenth century to 1914, Northerners made industrial and economic gains while the majority of Southerners remained peasants. This was partly due to the fact that the Catholic Church largely disintegrated in the South, as the state sold off Church lands to the wealthy landed elite. In addition, Catholic associations were nonexistent after 1889, which left the South neglected politically and civically. However, the death of Pope Pius X, coupled with the rise of socialist parties in Europe, led to the rise of a Catholic workers movement in the North, where there was a large industrial base. With the exception of a few labor unions in Puglia and Sicily, the Catholic and socialist labor movements were mainly concentrated in the North after 1914. Therefore, from the turn of the century until World War I, the South was left neglected by the political class and the Church, and clientelism became deeply ingrained in the Southern way of life. In the North, by contrast, political competition helped shape functioning public institutions and a thriving labor movement.

Moreover, the first decade of the twentieth century was characterized by relatively small periods of prosperity and long periods of instability; in this context, the deep-seated social and economic cleavage between the North and South continued to shape two separate compliance environments. The advent of Fascism only increased the political and economic divisions between the North and South. Mussolini's disdain for the South was reflected in industrial policies that concentrated economic development in the North, further increasing the economic di- 
vide. As a form of income supplementation, clientelism became one of the only means of distributing resources to the South.

After the fall of Fascism and the end of World War II, the rise of mass political parties in the North and the Christian Democratic political monopoly in the South deepened clientelistic networks and maintained the economic gap between the North and South. Because there was active political competition and progressive politics in the North, clientelism evolved in such a way that patrons provided public works projects to unions, construction companies, and professional organizations in return for members' votes, fostering functioning public institutions and a politically active citizenry in the North. In contrast, the Christian Democrats' political monopoly in the South created a form of clientelism that provided individualized benefits such as public employment to unqualified workers and tax favors. Contrary to the "amoral familism" argument, this study demonstrates that Italy's most important formal and informal institutions were responsible for shaping two distinct political and economic landscapes; both relied heavily on clientelism to support their constituents, but because the North invested in high quality public institutions, its residents are also more willing to invest in public institutions through taxation.

John D'Attoma is a Postdoctoral Researcher at the European University Institute, where he currently works on the project "Willing to Pay: Testing Institutionalist Theory with Experiments," funded by the European Research Council. His research uses causal inference to study taxation in Europe and the United States, and he has recently begun preliminary analysis examining under what conditions trust can emerge in the sharing economy. Ongoing and future research can be found on his website at www.johnwdattoma.com. 